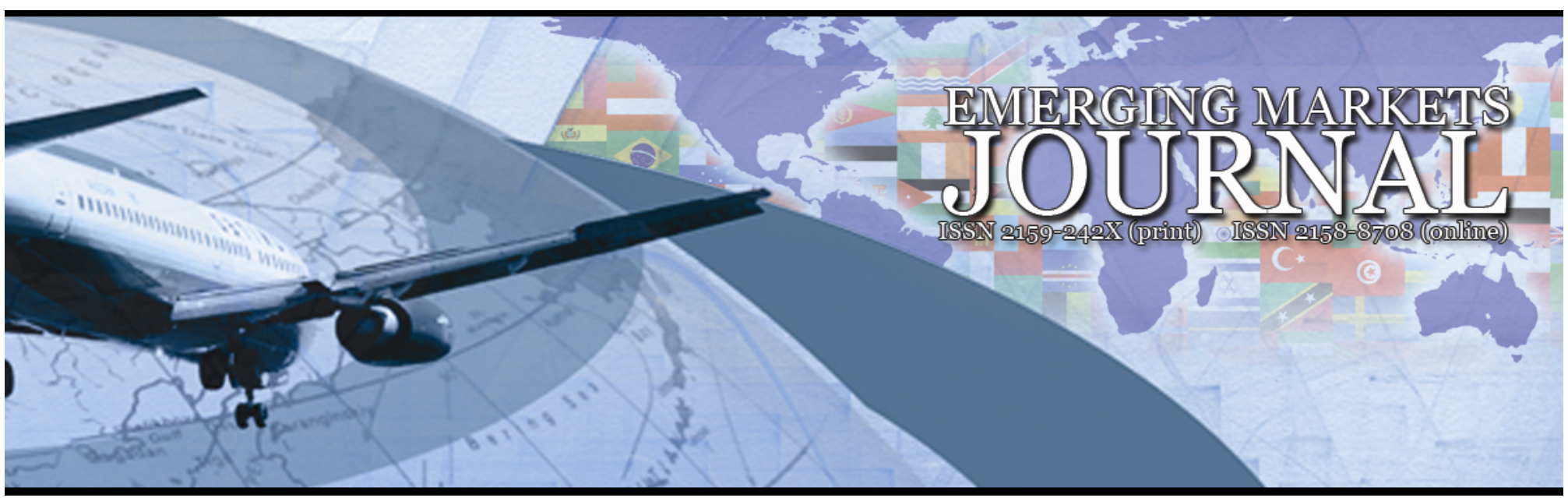

\title{
DOES EU-INTEGRATION CHANGE AGGLOMERATION PROCESS? THE IMPACT OF EU MEMBERSHIP PROCESS ON THE CITY-SIZE DISTRIBUTION OF TURKEY
}

\section{Engin Sorhun}

Bureau of Theoretical and Applied Economics, (BETA - THEME) University of Strasbourg, France, | e-mail: sorhun@unistra.fr

Volume 3 (2013) ｜ ISSN 2158-8708 (online) | DOI 10.5195/emaj.2013.35 | http://emaj.pitt.edu

\section{Abstract}

This paper aims to reveal the eventual impacts of European Union (EU) membership process and other conventional factors on the city-size distribution of a candidate country (Turkey). I can state main results as follows: Analyzing from different estimation methods the direct effect of the EU reforms on agglomerating forces rather than congesting forces are revealed to be dominant for Turkey. However, the main impact of the EU membership process has positive but modest coefficient that indicate the weak willingness of the country for EU reforms.

Keywords: Economic itegration, agglomeration, city-size distribution, EU, Turkey.

JEL Classification: F15, F22, R12, R23

\section{(CC) BY-NC-ND}

This work is licensed under a Creative Commons Attribution-Noncommercial-No Derivative

Works 3.0 United States License.

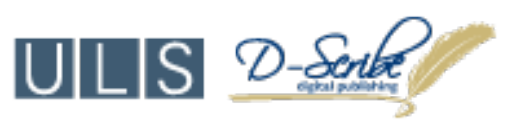

This journal is published by the University Library System of the University of Pittsburgh as part of its D-Scribe Digital Publishing Program, and is cosponsored by the University of Pittsburgh Press 


\title{
Does EU-Integration Change Agglomeration Process? The impact of $\mathbf{E} \mathbf{U}$ membership process on the city-size distribution of Turkey
}

\author{
Engin Sorhun
}

\section{I.Introduction}

One of the powerful regularities observed in rank-size distribution of cities is the Zipf's Law. The law points out that there is a logarithmic proportional relationship between rank and size of cities in linear form. In empirical studies, when cities are ordered by population size, a linear regression of their log-rank on their log-size yields a very high $\mathrm{R}^{2}$ and the slope coefficient of the log-size is generally found to be close to unity. When Zipf's Law holds, the largest city in the sample is more than $b$ times as large as the $b$ th largest city ${ }^{1}$.

As well as its empirical side, the theoretical side of the Zipf's Law is open to discussion. Despite the early empirical discovery, the quest for a robust theoretical model to explain such an empirical regularity remains elusive. For example Christaller (1933) had described the rank-size distribution as "a most incredible law" which was "nothing more than just playing with numbers". On the other hand, Getz (1979) further claimed that the descriptive model of the rank-size distribution seems quite founded at least on the theoretical level.

Though the criticism on the Law's theoretical inadequacy had long lasted the theoretical side is recently challenged by Mansury and Gulyas (2006) with the agent-based approach, by Krugman (1996) with the scale economy based model, by Page (1999) with the spatial computational model, and by Brakman et all (2001) with the congestion model.

However, this empirical report is completed by a functional specialization at the various levels of the urban hierarchy due to the indispensable linkage between geographical regularity and economic logic. The hierarchies of the urban networks are apparently very stable in time. However it does not necessarily correspond to equilibrium. But it is a dynamic processes impelled in the past.

It is known since Christaller (1933) and Lösch (1940) that a balanced space must comprise various categories of agglomerations: The small cities are used as interface between the rural world and the urban world, the average cities between the small centers and the regional metropolises, and so on, the capitals offering a privileged connection with the rest of the world. The sizes of the centers are decreasing according to the rank which they occupy in the hierarchy but their number is multiplied. The urban population residing in the small cities must be more important than that of the intermediate cities, the cumulated manpower of the intermediate cities superior to that of the regional cities, etc. to the capital.

It is known since Christaller (1933) and Lösch (1940) that a balanced space must comprise various categories of agglomerations: The small cities are used as interface between the rural world and the urban world, the average cities between the small centers and the regional metropolises, and so on, the capitals offering a privileged connection with the rest of the world. The sizes of the centers are decreasing according to the rank which they occupy in the hierarchy but their number is multiplied. The urban population residing in the small cities must be more important than that of the intermediate cities, the cumulated manpower of the intermediate cities superior to that of the regional cities, etc. to the capital.by certain models of geographical economy

Does Eu-Integration Change Agglomeration Process? The Impact Of Eu Membership Process On The City-Size Distribution Of Turkey 
(Krugman, 1991; Abdel-Rahman and Wang, 1995) and of endogenous growth (Waltz, 1996; Martin and Ottaviano, 2001; Baldwin, 2001) becomes visible.

On the other a spatial duality may be observable as a result of center-periphery logic. According to Parr (1985), the more the urban system is established the more the populations tend to be redistributed towards the small and average cities because of the negative effects (pollution, congestion, increase in ground rents... etc) which touches the great agglomerations. Afterwards decentralization takes place at the final stages of development when the urban congestion and the improvement of the infrastructures (in particular of transport and communication) lead to a delocalization of the activities towards periphery (Henderson et al, 1995).

The "rank-size" distribution gives in fact a synthetic description of the spatial organization. And it provides a modeling tool by means of which one watches the inter-temporal trend and development in the system of cities of a country and compares this trend with those of other countries. As rank-size distribution is a dynamic process fed in the course of the time by many geographical, social, politic and economic factors, international or regional integration movements can be considered as institutions with potential of feeding this dynamic process. In this respect, the EU, one of the most successful integration projects, can be thought to have more or less impact on the dynamics in the urbanization trends and the development in the rank-size distributions of its member and candidate countries.

This paper aims to empirically reveal whether or not the EU with its reform impulsion has impact on the dynamic city-size distribution of Turkey. The rest of the paper is organized as follows: section II presents two main estimators of Zipf's Law and outlines estimation model. Section III describes data. And finally Section IV presents main empirical findings and conclusion, respectively.

\section{II.Estimators for Zipf's Law}

\section{a. Pareto Estimator}

In brief, the Zipf's Law posits that if one ranks cities in descending order according to their population size, and then estimates the following equation:

$$
\log \left(R_{j}\right)=\alpha-\beta \log \left(M_{j}\right)
$$

where $\alpha$ is constant, $M_{j}$ is the size of city $j$ (measured by its population), and $R_{j}$ is the rank of city $j$ (rank 1 for the biggest city, rank 2 for the second biggest city, etc.). In empirical research $\beta$ is the estimated coefficient, giving the slope of the log-linear relationship between city size and city rank. It means that if and only if $\beta=1$, the Zipf's Law holds. If $\beta$ is smaller than unity, a more even distribution of city sizes results than the Zipf's Law predicted. That is to say, if $\beta=0$ all cities are of the same size. If $\beta$ is larger than unity, the large cities are larger than the Zipf's Law predicted, implying more urban agglomeration (the larger city is more than $b$ times as large as $b$ th largest city. Empirically, if the rank-size distribution holds, the question to pose is whether $\beta=1$ or not.

The empirical validity of Zipf's Law is debated by many authors (See Black and Handerson, 1999, 2003; Gabaix and Ionnides, 2004; Krugman, 1996; Soo, 2005). And even if they have different points of views, they reach a consensus on two points: (I) Zipf's Law holds proximately but not absolutely (the coefficient's value varies round the unity), and (II) Zipf's Law changes over time ${ }^{2}$.

The differences in rank-size distribution among different countries results from the balance between agglomerating forces and spreading forces which depend mostly on the economic development stages in which

Does Eu-Integration Change Agglomeration Process? The Impact Of Eu Membership Process On The City-Size Distribution Of Turkey 
countries are found. That is to say, change in $\beta$ value over time depends on the economic as well as social and political parameter changes. Following a progressive pattern, economic development begins with $\beta$ well below unity. As economy develops, $\beta$ value increases (agglomerating forces). And when the economy reaches a certain maturity level, then $\beta$ value starts to decrease (congestion or spreading forces) ${ }^{3}$.

\section{a. Hill Estimator}

Estimation of the $\beta$ values by many authors diverge according to whether they use the method of least squares ordinary (OLS) or the Hill (1975) estimator. Gabaix and Ioannides (2004) show that the Hill estimator (who is that of the method of the maximum of probability, when the Zipf's Law is checked), for a sample of $n$ cities with sizes $M_{1} \geq M_{j} \geq M_{n}$ is equal to:

$$
\beta=\frac{n-1}{\sum_{j=1}^{n-1}\left(\ln M_{j}-\ln M_{n}\right)}
$$

while the standard error for $\frac{1}{\beta}$ is given by the equation:

$$
\begin{aligned}
& \sigma_{n}\left(\frac{1}{\hat{\beta}}\right)=\left(\frac{\sum_{j=1}^{n-1} j\left(\ln M_{j}-\ln M_{j+1}\right)^{2}}{n-1}-\frac{1}{\hat{\beta}^{2}}\right)^{\frac{1}{2}}(n-1)^{-\frac{1}{2}} \\
& \text { If } \frac{1}{\hat{\beta}}>\sigma_{n}\left(\frac{1}{\hat{\beta}}\right) \text {, the standard error of the estimate of } \beta \text { is equal to: } \\
& \sigma_{n}(\hat{\beta})=\hat{\beta}^{2}\left(\frac{\sum_{j=1}^{n-1} j\left(\ln M_{j}-\ln M_{j+1}\right)^{2}}{n-1}-\frac{1}{\hat{\beta}^{2}}\right)^{\frac{1}{2}}(n-1)^{-\frac{1}{2}}
\end{aligned}
$$

According to Gabaix and Ioannides (2004), the Hill estimator, being more robust, corresponds better to the low part of the rank-size distribution of the cities that the estimator obtained through least squares ordinary (OLS).

Using OLS Soo (2005) rejects the empirical validity of the law of Zipf's Law for 73\% of the cases (53 of 73 countries). This supports the results of Rosen and Resnick (1980) who invalidated the assumption that a Pareto coefficient is equal to unity ( $82 \%$ of the cases of their sample). However through Hill estimator, invalidation rate in Rosen and Resnick (1980) is reduced to $40 \%$ of the cases (Soo, 2005) ${ }^{4}$.

Does Eu-Integration Change Agglomeration Process? The Impact Of Eu Membership Process On The City-Size Distribution Of Turkey 
To begin, write the estimation model first:

$$
\begin{aligned}
& \quad \beta_{T R, t}=\alpha_{0}+\alpha_{1} \ln M_{T R, t-1}+\alpha_{2} \ln I M I G_{E U \rightarrow T R, t}+\alpha_{3} \ln I M I G_{T R \rightarrow E U, t}+\alpha_{4} \ln I M I G_{i \rightarrow j, T R, t} \\
& +\alpha_{5} \ln I M I G_{j \rightarrow i, T R, t}+\alpha_{6} E U_{T R, t}+\varepsilon
\end{aligned}
$$

$\ln M_{T R, t-1}$ represents average city-size of the big cities and agglomerations for which criteria were defined in

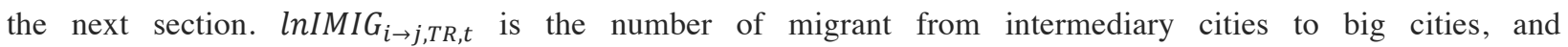
$\ln I M I G_{j \rightarrow i, T R, t}$ from big cities to intermediary cities in Turkey. And also international immigration flows was included as follows: $\ln I M I G_{E U \rightarrow T R, t}$ represents the number of immigrant from the EU to Turkey, and from Turkey to the EU, $\ln I M I G_{T R \rightarrow E U, t}$. And the major factors having impact on the city-size distribution of Turkey are presented as follows:

Wage growth: variance in average salary over time.

Wage-gap: the wage differential between average wage level of the EU-15 and that of Turkey.

Price-gap: the gap in price level (measured by CPI) between the EU-15 average and that of Turkey.

GDP growth: GDP growth rate of Turkey.

Openness: measurement of trade as \% of GDP.

FDI: yearly foreign direct investment flows of Turkey in \% of GDP.

Pop-growth: population growth rate of countries.

Basically this signifies that city-size distribution measured through $\beta$ value, of country (Turkey, $T R$ ) at time $t$ depends on city-size at time $t-1$, population flows from intermediary cities to big cities, from intermediary cities to abroad, from big cities to intermediary cities, from big cities to abroad at time $t$, and also on EU membership process.

And in order to evaluate the EU's effect, or more clearly the effect of the reforms realized in the path of EU membership on city-size distribution, I used an overarching index that is composed of 42 partial indicators selected by the EU Councils (Structural Indicators of European Economic Reform- SIEER) for monitoring former, new members and candidate countries (see Table 1).

Using the SIEER indicators I developed the global structural indicator (GSI). What does such an indicator serve? Using it one can reveal to what extent a country converges to the EU-15 average. It is expected that the more an economy realizes economic reforms in the way of EU membership process, the more its $\beta$-value (or city-size distribution) is subject to deep change over time. The question is whether or not membership process accelerates agglomerating forces rather than spreading forces, or vice versa. Though agglomerating forces are actually powerful within most of the EU-15 countries enter more or less under the effect of spreading forces thus one can think that convergence to the EU-15 threshold is a sign of activation of spreading forces in a member or accessing country. Nevertheless considering their development stages it would be more reasonable to expect that at the beginning of the convergence with the EU-15, membership process marked by a set of reforms will enhance $\beta$-value. Following an explanation about the GSI this prediction will be subsequently tested.

Does Eu-Integration Change Agglomeration Process? The Impact Of Eu Membership Process On The City-Size Distribution Of Turkey 
In addition to conventional variables showing the effects of the principal factors on city-size distribution GSI is used to capture the reform driven effect of the EU membership process. GSI deducted from 42 partial take value from -1 to +1.0 means that country is found at the average level of the EU-15. If a country's GSI is greater than 0 , then this country positively exceeds the EU-15 average. Otherwise, country remains behind the EU-15's average. Integrating GSI into the estimated model I aim to reveal the direct effect of the EU membership process through reforms on the dynamic city-size distribution of Turkey. As for econometric side using time series data arrangement will be more appropriate to the case.

\section{Data}

Two city definitions (city proper and agglomeration definitions ${ }^{5}$ ) and calculation method of $\beta$ value (Pareto and Hill estimators) are used. I use the city proper definition and the agglomeration definition with the threshold of more than 1.000.000 inhabitants. According to this demarcation, there are 18 city-proper-defined cities and 9 agglomerations in Turkey (see Table 2). However it implicitly suggests that the uneven distribution of large scale areas and small scale areas leads to migration flows between regions with more than 1.000.000 inhabitants and regions less than 1.000 .000 inhabitants.

Full data set with time series cover the period between 1985 and 2010. Data shortage limits time length of the study. As for dynamic change in city-size distribution one needs as large time perspective as possible. While the data set covering 25-year-period yields modest information about the development in city-size distribution it yields considerable information about the impact of EU reforms on this.

The whole data were provided from The Turkish Statistical Institute and Eurostat. The rank-size distribution is calculated for the time period. And I estimated the Pareto and Hill estimators so as to cover the whole period.

\section{Empirical Results and Conclusion}

It is useful to take a larger look at the evolution in Turkey's $\beta$ value. Graphics 1 and 2 show the course that Turkey's $\beta$ value followed between 1955 and 2011. It is important especially because this period covers even the years when immigration towards Western European countries and migration towards large urban areas gained acceleration. Thus those intensifying population within-flows and out-flows is considered to have determining impact on $\beta$ value. They emphasize two main movements: first, the vague of migrants towards big cities within the country accelerated agglomeration process by diminishing the size of the intermediary cities in favor of the growing size of the big cities over time. And second, the immigration towards Western Europe that is mostly fed by intermediary cities contributed to the acceleration in agglomeration process by undermining the size of the intermediary cities.

The graphics show two things about city-size distribution: first, $\beta$ value has stabilized since 1995 after it sharply and rapidly rose until 1995. Second, the strongest acceleration in $\beta$ value in favor of agglomeration was observed between 1985 and 1995. At the beginning of the 1990's Turkey's $\beta$ value reached the unity and her ranksize distribution curve took linear form at that time. And Turkish big cities, compared with intermediary cities, started to become larger than they had been before.

To see more clearly to what extend factors having impact on Turkey's $\beta$ value I estimated the Equation 2 through time series regression. And I run the model according to different city definitions and estimators.

Does Eu-Integration Change Agglomeration Process? The Impact Of Eu Membership Process On The City-Size Distribution Of Turkey 
As it is presented in Table 3 remarkably $R^{2}$ is the highest for Pareto estimator based on agglomeration definition. This supports Brakman et al (2001) prediction that agglomeration definition fits better the Zip's Law. Nevertheless there is not too large differentiation among estimated coefficients. It is important for credibility of the estimation.

Wage and price gaps negatively influence $\beta$ while FDI, openness, growth rate and progress in average wage level have positive impact on $\beta$ value. That is to say, two kinds of factors, agglomeration-decelerating and agglomeration-accelerating factors work together. Expected signs are satisfied as in the previous literature: GDP growth and openness are positively the most powerful effects while wage-gap and price-gap are negatively most powerful effects.

Now deal with the backbone of the model: migration and immigration flows and EU membership process. City-size distribution largely depends on city population at time $(t-1), \ln M_{T R, t-1}$. Its effect varies in $\ln$-term between 0.20 and 0.36 .

$\ln I M I G_{i \rightarrow j, T R, t}$ represents population movement from intermediary city to big city at time $t$ ( sign of agglomerating forces) and $\ln I M I G_{j \rightarrow i, T R, t}$ represents population movement from big city to intermediary city at time $t$ ( sign of "resistant factors" ${ }^{\text {) }}$. Migration towards agglomerations within the country is a very determinant factor in city-size distribution. Its impact on $\beta$ value varies between 0.05 (min.) and 0.10 (max.). Considering the development stage of Turkey we can tell that the impact of "congesting forces", $\ln I M I G_{j \rightarrow i, T R, t}$, are limited. However, the estimations confirm the prediction that beyond a certain threshold of the development process congesting forces would appear. Turkey has not reached that threshold yet.

As for immigration, Turkish immigration to EU-15 $\ln I M I G_{T R \rightarrow E U, t}$ has relatively smaller effect than return immigration from the EU-15, $\ln I M I G_{E U \rightarrow T R, t}$, has. This situation can be explained as follows: immigration vague generally occurs from intermediary cities to abroad. For this reason a fall in intermediary cities' population causes a relative raise in big cities' population and a change in $\beta$ value so as to indicate acceleration in agglomeration process within the country. For this reason $\ln I M I G_{T R \rightarrow E U, t}$ gives positive sign. And contrarily, returns immigrants coming back to intermediary cities create a reverse effect. Return immigration to intermediary cities counterbalance the relative raise in $\beta$ value. For this reason $\ln I M I G_{E U \rightarrow T R, t}$ gives negative sign.

We see clearly the impacts of agglomerating forces, $\left(\ln I M I G_{i \rightarrow j, T R, t}, \ln I M I G_{T R \rightarrow E U, t}\right.$ ), are superior to that of resistant forces $\left(\ln I M I G_{j \rightarrow i, T R, t}, \ln I M I G_{E U \rightarrow T R, t}\right)$. This shows that for Turkey agglomeration process will continue. The direct effect of the EU on the dynamic in city-size distribution is revealed through EU variable (GSI) that captures economic structural progress of countries in the way of EU membership. Its estimated coefficient is found positive but modest (between 0.06 and 0.09 ) compared with those of other variables. This finding explicitly shows that EU membership process activates through reforms certain dynamics pushing $\beta$ value. Considering the upward movements of the estimated $\beta$ value (see graphics 1 and 2) one can say that EU membership process has impulsively contributed to the city-size evolution within Turkey. On the other hand whether this impact is modest or strong depends primarily on the willingness of the country for reforms. A weak coefficient may be explained by such a reasoning.

Does Eu-Integration Change Agglomeration Process? The Impact Of Eu Membership Process On The City-Size Distribution Of Turkey 


\section{V.References}

1. Abdel-Rahman, H. and Wang, P. (1995), Toward a general-equilibrium theory of a core-periphery system of cities, Regional Science and Urban Economics, 25, pp. 529-546.

2. Auerbach, F. (1913): Das Gesets der Bevolkerungsknzentration. Petermann's Mitteilungen, 59:74-76

3. Baldwin, R.E. (2001), Core-periphery model with forward-looking expectations, Regional Science and Urban Economics, 31, pp. 21-49.

4. Black, D. and Henderson, V. (1998), Spatial Evolution of Population and Industry in the United States, The American Economic Review, Vol. 89, No. 2, Papers and Proceedings of the One Hundred Eleventh Annual Meeting of the American Economic Association (May, 1999), pp. 321-327

5. Black, D. and Henderson, V. (1999), A theory of Urban Growth, Journal of Political Economy, 107(2), pp. 252-84.

6. Black, D. and Henderson, V. (2003), Urban evolution in the USA, Journal of Economic Geography, 3, 343372 .

7. Brakman, S, Garretsen, H., and van Marrewijk, C. (2001), An Introduction to Geographical Economics, Cambridge, UK: Cambridge University Press (Third edition, 2005).

8. Christaller, W. (1933), Die Zentralen Orte in Suddeutschland, Iéna; English translation C.W. BASKIN, 1966, Central places in Southern Germany, Englewood Cliffs, Prentice-Hall.

9. Embrechts, P., Kluppelberg, C, Mikosch, T. (1997), Modelling External Events for Insurance and Finance, Springer, New York.

10. Eurostat (2008), Eurostat data set, www.eurostat.eu, [acceded 10/12/2007]

11. Gabaix, X., Ioannides, Y. (2004), The evolution of city size distributions, Handbook of Regional and Urban Economics, in: J. V. Henderson \& J. F. Thisse (ed.), Handbook of Regional and Urban Economics, edition 1, volume 4, chapter 53, pages 2341-2378

12. Getz, M. (1979), Optimum city size: fact or fancy? Law and Contemporary Problems, Vol. 43, No. 2, Growth Policy in the Eighties (Spring, 1979), pp. 197-210

13. Henderson, V., Kuncoro, A., and Turner, M. (1995), Industrial Development in Cities, Journal of Political Economy, 103(5), pp. 1067-1090.

14. Hill, B.M. (1975), A simple approach to inference about the tail of a distribution, Annals of Statistics 3, pp $1163-1174$.

15. Hill, B.M. (1996a), The Self-Organizing Economy, Blackwell.

16. Hill, B.M. (1996b), Confronting the mystery of urban hierarchy, Journal of the Japanese and International Economics, 10:399-418.

17. Krugman, P. (1991), Geography and trade, MIT Press.

18. Krugman, P. (1996), The Self-Organizing Economy, Blackwell

19. Krugman, P. and Livas-Elinzondo R. (1996), Trade Policy and the Third World Metropolis, Journal of Development Economics, 49(1), pp. 137-50.

20. Lösch A. (1940), Die räumliche Ordnung der Wirtschaft, Iéna, G. FISCHER, English translation (1954), The economics of location, New Haven, Yale University Press.

21. Mansury, Y. and Gulyas, L. (2006), The emergence of Zipf's law in a system of cities: an agen-based simulation approach, Journal of Economic Dynamics \& Control, in the course of publishing.

22. Martin, P. and Ottaviano, G.I.P. (2001), Growth and Agglomeration, International Economic Review, 42, 947-968.

23. Page, S. (1999), On the emergence of cities, Journal of Urban Economics, 45, 184-208.

Does Eu-Integration Change Agglomeration Process? The Impact Of Eu Membership Process On The City-Size Distribution Of Turkey 
24. Parr, J.B. (1985), A note on the size distribution of cities over time, Journal of Urban Economics, 18(2), pp. 199-212.

25. Pareto, V. (1897), Cours d'économie politique, Lausanne, Switzerland:Rouge.

26. Pumain D. and Moriconi-Ebrard F. (1997), City size distributions and metropolisation, Geojournal, $n^{\circ} 43-4$, pp.307-314.

27. Rosen, K. T., Resnick, M., (1980), The size distribution of cities: An examination of the Pareto law and primacy. Journal of Urban Economics 8 (2), $165\{186$.

28. Rosenstein-Rodan, P. (1943), Problems of industrialization in eastern and south-eastern Europe, Economic Journal, 53, 2002-211.

29. Soo, K.T. (2005), Zipf's law for cities: a cross-country investigation, Regional Sciences and Urban Economics, 35, 239-263.

30. Turkish Statistical Institute (2011), The census 2011.

31. Zipf, G.K. (1949), Human Behavior and the Principle of Least Effort, Addison-Wesley Press

32. Waltz, U. (1996), Transport costs, Intermediate Goods, and Localized Growth, Regional Science and Urban Economics, 26, 671-695.

Table 1: Structural Indicators of European Economic Reform

\begin{tabular}{|c|c|}
\hline $\begin{array}{l}\text { 1. Headline Indicators } \\
\text { Gross domestic product } \\
\text { Employment } \\
\text { Research and development spending } \\
\text { ICT (Inf. Com. Tech.) expenditure } \\
\text { Prices in network industries } \\
\text { Business investment } \\
\text { Trade integration } \\
\text { At risk of poverty before and after social transfers } \\
\text { Long-term unemployment } \\
\text { Dispersion of regional employment rates } \\
\text { Further education } \\
\text { Greenhouse gas emissions }\end{array}$ & $\begin{array}{l}\text { 5. Economic Reform } \\
\text { Prices } \\
\text { Market structure in network industries } \\
\text { Public procurement } \\
\text { State aids }\end{array}$ \\
\hline $\begin{array}{l}\text { 2. General Economic Background } \\
\text { Labour productivity } \\
\text { Employment growth } \\
\text { Inflation rate } \\
\text { Unit labour cost growth } \\
\text { Public balances } \\
\text { General government debt }\end{array}$ & $\begin{array}{l}\text { 6. Social Cohesion } \\
\text { Inequality of income distribution } \\
\text { Persistent risk of poverty } \\
\text { Population living in jobless households }\end{array}$ \\
\hline $\begin{array}{l}\text { 3. Employment } \\
\text { Effective active exit rate } \\
\text { Gender pay gap in unadjusted form } \\
\text { Tax rate on low wage earners } \\
\text { Life-long learning } \\
\text { Accidents at work } \\
\text { Unemployment rate }\end{array}$ & $\begin{array}{l}\text { 7. Environment } \\
\text { Energy intensity of the economy } \\
\text { Volume of transport relative to GDP } \\
\text { Modal split of transport } \\
\text { Urban air quality } \\
\text { Municipal waste } \\
\text { Renewables in electricity consumption }\end{array}$ \\
\hline $\begin{array}{l}\text { 4. Innovation and Research } \\
\text { Spending on human resources } \\
\text { Level of internet access } \\
\text { Science and technology graduates } \\
\text { Patents } \\
\text { Venture capital investments }\end{array}$ & \\
\hline
\end{tabular}


Graphic 1: City-size distribution of Turkey with Pareto estimator

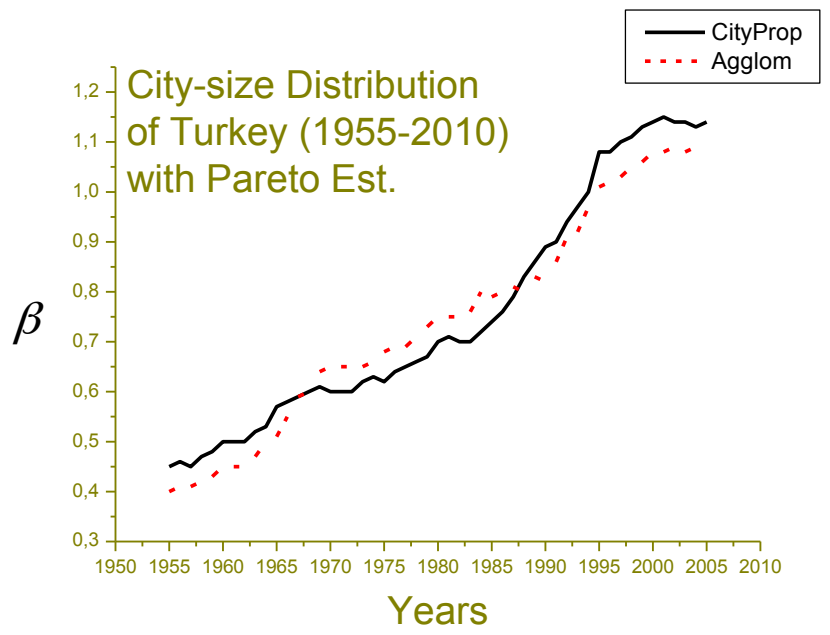

Graphic 2: City-size distribution of Turkey with Hill estimator

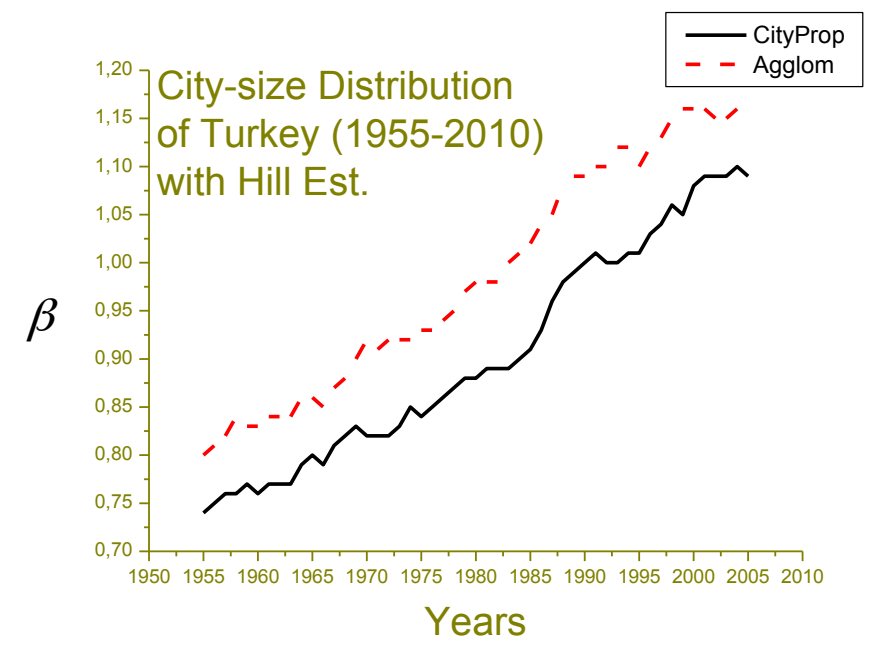

Does Eu-Integration Change Agglomeration Process? The Impact Of Eu Membership Process On The City-Size Distribution Of Turkey 
Table 2 : City size according to city proper and agglomeration definitions

\begin{tabular}{lll}
\hline City Name & City Proper & Agglomeration \\
\hline Adana* & 2.006 .650 & 1.611 .262 \\
Ankara* & 4.466 .756 & 4.140 .890 \\
Antalya* & 1.789 .295 & 1.127 .634 \\
Balikesir & 1.118 .313 & 649.423 \\
Bursa* & 2.439 .876 & 1.979 .999 \\
Diyarbakir & 1.460 .714 & 855.389 \\
Gaziantep* & 1.560 .023 & 1.342 .518 \\
Hatay & 1.386 .224 & 681.665 \\
Mersin* & 1.595 .938 & 1.056 .331 \\
Istanbul* & 12.573 .836 & 11.174 .257 \\
Izmir* & 3.739 .353 & 3.175 .133 \\
Kayseri & 1.165 .088 & 895.253 \\
Kocaeli & 1.437 .926 & 894.242 \\
Konya* & 1.959 .082 & 1.412 .343 \\
Manisa & 1.319 .920 & 841.059 \\
K.maras & 1.004 .414 & 584.726 \\
Samsun & 1.228 .959 & 725.111 \\
S.urfa & 1.523 .099 & 919.832 \\
\hline TOTAL & 43.775 .466 & 27.020 .367 \\
\hline
\end{tabular}

Source: Turkish Statistical Institute, the census 2011

* denotes agglomerations. 
Table 3: The impacts of the variables on the city-size distribution of Turkey

\begin{tabular}{|c|c|c|c|c|}
\hline & \multicolumn{2}{|c|}{$\beta$ with Pareto } & \multicolumn{2}{|c|}{$\beta$ with Hill estimator } \\
\hline Variables & $\begin{array}{c}\text { City Proper } \\
\text { I }\end{array}$ & $\begin{array}{c}\text { Urban Agglomeration } \\
\text { II }\end{array}$ & $\begin{array}{c}\text { City Proper } \\
\text { III }\end{array}$ & $\begin{array}{c}\text { Urban Agglomeration } \\
\text { IV }\end{array}$ \\
\hline$\alpha_{0}$ & $\begin{array}{l}3.121001 \\
(0.73413)\end{array}$ & $\begin{array}{c}6.441375 \\
(0.140473)\end{array}$ & $\begin{array}{c}9.111630 \\
(0.012121)\end{array}$ & $\begin{array}{l}10.222454 \\
(1,232587)\end{array}$ \\
\hline $\ln M_{T R, t-1}$ & $\begin{array}{c}0.259721 \\
(3.717440)\end{array}$ & $\begin{array}{c}0.262350 \\
(7.164872)\end{array}$ & $\begin{array}{c}0.200405 \\
(6.166015)\end{array}$ & $\begin{array}{c}0.365517 \\
(2.149015)\end{array}$ \\
\hline $\ln I M I G_{i \rightarrow j, T R, t}(+)$ & $\begin{array}{c}0.221015 \\
(3.155731)\end{array}$ & $\begin{array}{c}0.200444 \\
(5.009813)\end{array}$ & $\begin{array}{c}0.140792 \\
(4.020072)\end{array}$ & $\begin{array}{c}0.162852 \\
(3.789456)\end{array}$ \\
\hline $\ln I M I G_{j \rightarrow i, T R, t}(-)$ & $\begin{array}{c}-0.081410 \\
(-3.341472)\end{array}$ & $\begin{array}{l}-0.102580 \\
(-4.090404)\end{array}$ & $\begin{array}{c}-0.071334 \\
(-4.004401)\end{array}$ & $\begin{array}{c}-0.050019 \\
(-2.237846)\end{array}$ \\
\hline $\ln I M I G_{E U \rightarrow T R, t}(-)$ & $\begin{array}{l}-0.039284 \\
(2.921424)\end{array}$ & $\begin{array}{l}-0.031783 \\
(-4.161622)\end{array}$ & $\begin{array}{c}-0.060229 \\
(-3.960131)\end{array}$ & $\begin{array}{c}-0.056560 \\
(-6.000450)\end{array}$ \\
\hline $\ln I M I G_{T R \rightarrow E U, t}(+)$ & $\begin{array}{c}0.037678 \\
(2.964034)\end{array}$ & $\begin{array}{c}0.008158 \\
(5.122181)\end{array}$ & $\begin{array}{c}0.042414 \\
(4.005118)\end{array}$ & $\begin{array}{c}0.039844 \\
(4.689547)\end{array}$ \\
\hline lnWage-growth & $\begin{array}{c}0.047812 \\
(5.723450)\end{array}$ & $\begin{array}{c}0.041840 \\
(4.937915)\end{array}$ & $\begin{array}{c}0.033515 \\
(4.783017)\end{array}$ & $\begin{array}{l}0.050214 \\
(3.852465\end{array}$ \\
\hline lnWage-gap & $\begin{array}{c}-0.099504 \\
(-5.050471)\end{array}$ & $\begin{array}{c}-0.059819 \\
(-3.950544)\end{array}$ & $\begin{array}{c}-0.050024 \\
(-5.321180)\end{array}$ & $\begin{array}{c}-0.062889 \\
(-5.964713)\end{array}$ \\
\hline lnPrice-gap & $\begin{array}{c}-0.066694 \\
(-4.274024)\end{array}$ & $\begin{array}{c}-0.071989 \\
(-4.417751)\end{array}$ & $\begin{array}{c}-0.045556 \\
(4.785651)\end{array}$ & $\begin{array}{c}-0.082146 \\
(4.242240)\end{array}$ \\
\hline lnGDP-growth & $\begin{array}{c}0.112042 \\
(3.730001)\end{array}$ & $\begin{array}{c}0.120013 \\
(3.931110)\end{array}$ & $\begin{array}{c}0.094415 \\
(5.389067)\end{array}$ & $\begin{array}{c}0.078254 \\
(5.208540)\end{array}$ \\
\hline lnOpenness & $\begin{array}{l}0.0861333 \\
(4.132394)\end{array}$ & $\begin{array}{c}0.114404 \\
(4.197476)\end{array}$ & $\begin{array}{c}0.050642 \\
(3.941546)\end{array}$ & $\begin{array}{c}0.089999 \\
(3.789524)\end{array}$ \\
\hline Ln FDI & $\begin{array}{c}0.069888 \\
(5.111413)\end{array}$ & $\begin{array}{c}0.091902 \\
(3.160041)\end{array}$ & $\begin{array}{c}0.059841 \\
(5.078484)\end{array}$ & $\begin{array}{l}0.0902148 \\
(4.665659)\end{array}$ \\
\hline lnPop-gowth & $\begin{array}{c}0.031111 \\
(5.102224)\end{array}$ & $\begin{array}{c}0.022214 \\
(3.664478)\end{array}$ & $\begin{array}{c}0.021111 \\
(6.113331)\end{array}$ & $\begin{array}{c}0.048521 \\
(6.568500)\end{array}$ \\
\hline$E U_{T R, t}$ & $\begin{array}{c}0.031122 \\
(4.198751)\end{array}$ & $\begin{array}{c}0.041000 \\
(4.325646)\end{array}$ & $\begin{array}{c}0.032147 \\
(4.686861)\end{array}$ & $\begin{array}{c}0.025840 \\
(5.165847)\end{array}$ \\
\hline$R^{2}$ & 0.76 & 0.80 & 0.54 & 0.58 \\
\hline
\end{tabular}

All values (out of constant terms) are significant at $0.1 . \mathrm{t}$ values are presented in parenthesis.

Does Eu-Integration Change Agglomeration Process? The Impact Of Eu Membership Process On The City-Size Distribution Of Turkey 
Endnotes:

${ }^{1}$ Although Auerbach (1913) is considered as the first scholar who observed the empirical regularity in the size of distribution of cities this phenomena was recognized "Zipf's Law" due to Zipf (1949) who propagated this regularity. What Zipf did is that he had tried to approximate the distribution of city sizes with a Pareto distribution. This is also known «power law ». This basically says that the Pareto exponent of the distribution of city sizes is equal to unity.

${ }^{2}$ For example look at empirical studies on the USA, Caroll (1982) says that Zipf's Law does not always hold for the United States. Rosen and Resnik (1980) find that the Pareto coefficient is equal to 0.84 for the USA. Black and Handerson (1998) showed that the slope of the city-size distribution slowly increased in the USA over the course of the twentieth century. See also Dobkins and Ioannides (2000) and Eaton and Eckstein (1997) who find for Japan and France that Zipf's Law nearly holds and the coefficient changed over time. I will explain in the next section from what the differences between the empirical studies realized with the same data result.

${ }^{3}$ For example, looking at the graphics 1 and 2, we can say that Turkey is found at a stabilized level of its agglomeration process. See Sorhun (2007) for more detailed comparative study covering the new member and accessing countries of the EU.

${ }^{4}$ With a better determination of the standards errors, the Hill method thus provides an estimation of the Pareto coefficient which leads to a more systematic checking of the Zipf's Law. Nevertheless, this estimation method is subject to many criticisms, in particular as for its capacity to represent the lognormal distribution of the cities since their demographic growth is not independent of their size, which is a condition of rejection of the Zipf's Law (Embrechts, Kluppelberg and Mikosch, 1997; Pumain and Moriconi-Ebrard, 1997).

${ }^{5}$ Brakman et al (2001) describe two ways in term of the definition of a city. The firs one is to limit the city to its legal boundaries, the so-called city proper (like in Rosen and Resnick, 1980). The second one is to define the city as the agglomeration (like in Black and Handerson, 1998) that is thought to constitute an economic unit and to put out official city definitions.

${ }^{6}$ Essentially, agglomeration forces and spreading (or congestion/disagglomeration forces) works against each others. But considering the development levels of the new member and accessing countries I decided that it would be better to rename and interpret "spreading forces" as "resistant factors" to agglomeration. 